\title{
INCENTIVE PROGRAMS TO PROMOTE STARTUPS: A BRAZILIAN CASE
} PROGRAMAS DE INCENTIVO A STARTUPS: UM CASO BRASILEIRO

Recebido em 12.09.2018. Aprovado em 20.02.2019

\section{Francisco Waldney Moreira}

francomoreiratalk@gmail.com

Programa de Pós-Graduação em Administração (PPGA), Universidade de Brasília (UnB), Brasília/DF, Brasil ORCID: https://orcid.org/0000-0002-1639-8717

\section{Isabela Miranda Martins}

isa.mmartins.im@gmail.com

Programa de Pós-Graduação em Administração (PPGA), Universidade de Brasília (UnB), Brasília/DF, Brasil ORCID: https://orcid.org/0000-0002-3332-9852

\section{Bruno Alencar Pereira}

alenbruno@gmail.com

Programa de Pós-Graduação em Administração (PPGA), Universidade de Brasília (UnB), Brasília/DF, Brasil ORCID: https://orcid.org/0000-0002-9534-242X

\section{Josivania Silva Farias}

josivania@,unb.br

Programa de Pós-Graduação em Administração (PPGA), Universidade de Brasília (UnB), Brasília/DF, Brasil ORCID: http://orcid.org/0000-0002-1421-3280

\begin{abstract}
This study aimed to verify the practical implications of innovation incentive programs in the development of a carpooling startup from Brazilian Federal District. It is a case study in which the startup was supported by programs to encourage innovation. Interviews were conducted with the managers of the startup, with the purpose of evaluating the confluence and applicability of the programs to the needs of the business, evidencing the impact of that programs in its development. Empirical evidence was treated through content analysis with a priori categorization, with the managers' perspectives being compared with the factors of incentive to startups - investment, mentoring and support for market insertion. The results demonstrated that financial assistance, managerial training and institutional networking contributed to the startup development. The study provides an analysis of startups development factors and contributes to the improvement of innovation incentive programs.
\end{abstract}

Keywords: Innovation incentive programs. Startup. Investment. Mentoring. Market insertion.

\section{Resumo}

Este estudo objetivou verificar os efeitos de programas de incentivo à inovação no desenvolvimento de uma startup de carpooling do Distrito Federal brasileiro. Trata-se de um estudo de caso em que a startup recebeu apoio de programas de incentivo à inovação. Os gestores da startup foram entrevistados com o intuito de avaliar a confluência dos programas às necessidades do empreendimento. $\mathrm{O}$ estudo usou a análise de conteúdo com categorização a priori, contrapondo as perspectivas dos gestores e os fatores de incentivo - investimento, mentoria e apoio à inserção mercadológica. Os resultados mostraram que assistência financeira, capacitação gerencial e networking institucional contribuíram para o desenvolvimento da startup. O estudo oferece uma análise de fatores para o desenvolvimento de startups e contribui com o aprimoramento dos programas de incentivo à inovação.

Palavras-chave: Programas de incentivo à inovação. Startup. Investimento. Mentoria. Inserção mercadológica. 


\section{Introduction}

In the context of increased competitiveness, startups appear as an innovative alternative faced to companies already established in the market, representing an important source of economic growth. In pursuit of a viable business model in a highly uncertain environment, the development of startups requires a considerable level of support and investment, which is usually carried out by public sector organizations or through public-private partnerships (Audretsch, Heger, \& Veith, 2014).

Institutions that support innovative initiatives ruled by local laws and policies to encourage innovation do not always provide the necessary assistance for the progress of companies in the development stage. This is due to a possible gap in the alignment between policies, incentive programs, and the needs faced by entrepreneurs in the process of growth (Doruk \& Söylemezoğlu, 2014).

Therefore, it becomes relevant to identify how entrepreneurs perceive the forms of support received through incentive programs, as well as their impact on the development of a startup in the market. In this sense, the proposed study aimed to verify the practical implications of innovation incentive programs in the performance of a carpooling startup from Brazilian Federal District, analysing the perception of its founders and evaluating if that programs are addressed to the real needs of these businesses.

The article focuses initially on the process of developing startups and on policies to encourage innovation. In addition, the established policies that guide the relationship between the public sector and innovation entrepreneurship are discussed. Finally, from a case study, the evaluation of the confluence and applicability of the incentive programs to the innovation, developmental and consolidation needs of the analyzed startup is presented.

\section{Startups and development process}

A startup is defined as an organization of temporary character, operating under conditions of high uncertainty, which seeks a profitable business model from the development of an innovative idea (Blank, 2012; Ries, 2011). In a scenario of constant change, startups can pose a competitive threat to established firms by introducing innovations in the market, contributing to increased economic growth (Fritsch \& Aamoucke, 2013).

In this sense, according to Blank (2012), startups seek a repeatable and scalable business model, that is, with the ability to offer a product or service under certain standards to a growing number of customers. Thus, the scale-up feature of startups implies investments in physical capital and high investments in infrastructure. The investment in physical capital is exercised by the company itself, while infrastructure investment, because it is large scale, is usually carried out by the public sector or through public-private partnerships (Audretsch et al., 2014). Thus, the growth potential of startups usually requires high levels of external investment (Blank, 2012), which may hinder the entry of these companies into the market.

Doruk and Söylemezoğlu (2014) note that especially in developing countries, the main impediments to the progress of startups and innovations are bureaucratic and cost barriers. In this sense, Audretsch et al. (2014) emphasize that infrastructure plays an extremely important role in entrepreneurial activity, and that there is a positive relationship between the startup activity and the infrastructure for its growth.

The process of developing technology-based startups is therefore influenced by several aspects. Kasabov (2015) through a literature review on entrepreneurship, highlights, in addition to the financial resources, the human resources available in the organization and the networks of collaboration as essential factors of success of a startup. The human resources present in the organization are one of the most important factors for the success of a startup, because human capital would be an important source of investment attraction for the development of innovative microenterprises. Concerning to networking factor, it is 
extremely important that startup managers develop relationships in collaborative networks, forming alliances and gaining access to resources and emotional support (Kasabov, 2015).

Among the factors mentioned, in addition to the need for financial resources to start operations, startups need to seek knowledge about the product or service they will offer, as well as gain experience in the market in which they intend to enter. In this sense, support for the development of startups should consist of financial incentive, mentoring and support for market insertion, so that they can obtain market competitiveness (Ramaciotti, Muscio, \& Rizzo, 2017).

Song, Podoynitsyna, Van Der Bij and Halman (2008) enumerate eight universal success factors for the development and performance related to startups, namely: (1) supply chain integration; (2) market scope; (3) company age; (4) size of the founder team; (5) financial resources; (6) marketing experience; (7) industry experience; and (8) intellectual property protection. Song et al. (2008) argue that factors (1) supply chain integration, (2) market scope, (5) financial resources, (6) marketing experience, (7) industry experience, and (8) intellectual property protection can be influenced by policies and support programs from organizations that support the development of startups.

Given the factors that influence startup development success, certain incentive policies can then be implemented to facilitate the activities of these companies and promote their insertion into the market. The Organization for Economic Cooperation and Development (OECD, 2010) stresses that in Latin America, governments should turn their attention and efforts to the following objectives: (1) to expand the quantity and quality of business opportunities; (2) facilitate access for potential entrepreneurs to work experience; (3) improve access to finance; (4) encourage innovation at all levels; and (5) make entrepreneurship development a long-term social investment.

Thus, the factors influencing the growth of startups involve the importance of policies and support programs for the consolidation and development of these ventures in the market. In this sense, Colombelli, Krafft and Vivarelli (2016) emphasize the importance of supporting startups, since they stimulate the improvement and dynamism of the markets, representing a source of technological development and economic growth.

\section{Policies to promote innovation and support to the startups development}

According to Faria and Fonseca (2015) the importance assumed by innovation for organizations in the current scenario of competitiveness, is reinforced by scholars and practitioners from the organizational area, but there is still little production on how to develop and maintain a culture of innovation aligned with assertive development policies.

The creation of new ventures addressed to the technological development, as related to startups, is considered a relevant path for economic growth that can contribute to regional economic performance. In the same way, innovation is an essential element in the business strategy to obtain competitive advantage and value creation in unstable and turbulent environments (Fiates, Fiates, Serra, \& Ferreira, 2010).

Policies to promote entrepreneurial activity and innovation have a positive effect on entrepreneurship in which societies with a greater number of innovative entrepreneurs present higher levels of business activity and economic performance (Castaño-Martínez, Méndez-Picazo, \& Galindo-Martín (2002). However, several factors can act as barriers to the development and growth of these enterprises, both at the contextual level and at the intra-organizational level, but there is still no consensus on the need for public intervention to remove some of these barriers (Ramaciotti et al., 2017).

According to Söderblom, Samuelsson, Wiklund, and Sandberg (2015), there are three conceptually distinct reasons why government grants for new ventures can be beneficial: (1) subsidies can stimulate new ventures to increase their investment in innovation; (2) government subsidies are particularly relevant 
to new ventures, as they are able to reduce information asymmetries and market failures; (3) government financial contributions can legitimize the new venture, signaling that the startup is certified by a reliable source, making it more attractive to possible resource sources.

This view is reinforced by Fiates et al. (2010), demonstrating the beneficial results of startup interactions with government agencies, national and foreign partners, suppliers or users of goods and services, research centers, trade associations, among others, showing that such interactions contribute significantly to the diffusion of innovation. In this context, Castaño-Martínez et al. (2015) indicate that governments can play an important role in reducing costs and barriers, as well as in improving the attribution of entrepreneurial talents to innovation. Prominent interventions include entrepreneurship programs such as the Venture Capital Limited Partnership and Advance Queensland in Australia, Yozma in Israel, Startup Chile and iNNpulsa Colombia, representing effective mechanisms to support entrepreneurs in overcoming obstacles and encouraging startups to spread innovations that stimulate the economy.

According to Ramaciotti et al. (2017) the impact of innovative business support policies basically falls into two categories: intensive policies through financial support, whether in the form of grants, loans or guarantees; and soft policies through consultancies and mentoring aimed at the development of the enterprise. Ramaciotti et al. (2017) argue that the impact of soft policies on the growth of the supported enterprise is greater than the impact of intensive policies made possible through financial contributions, mainly in the "ignition phase" of the startup, when the new enterprise demands access to technologies, guidance and advice on design, and business management skills.

Söderblom et al. (2015) point out that the design of government programs (i.e. their structure, nature and form of subsidies, as well as their attractiveness, prestige and competitiveness) are critically important and can serve as a certification of the quality of new ventures in the market.

However, government policies to encourage innovation can be poorly conceived, becoming a source of poor allocation of resources by favoring inefficient business, or by introducing distortions in business growth. The indicators of these unintended effects would be the relatively weak performance of the supported startups reflecting the low productivity of the enterprise, slower growth and lower survival rate after the intervention (Butler, Galassi \& Ruffo, 2016).

According to Mason and Brown (2013) knowing the most appropriate moment to support startups is also a critical point in innovation policies. Given that business growth is significantly uneven and episodic, identifying when a startup is about to accelerate its growth is extremely difficult. Identifying the points of growth gain is an extremely challenging task for government agencies to encourage innovation. According to the author, longitudinal monitoring of the venture could help in the process of observation, identification and satisfaction of needs, according to the speed of maturity and stage of development of the startup. A potential indicator of growth ambition is the desire to internationalize the business. Recent research shows that export-oriented entrepreneurs are more likely to grow than those who operate only in domestic markets. The following is an overview of the innovation incentive programs that supported the startup analyzed in the present study.

\section{The innovation incentive programs}

The Federal District Research Support Foundation (Fundação de Apoio à Pesquisa do Distrito Federal FAPDF) was established by District Law No. 347, dated November 4, 1992, and amended by District Law No. 3,652, of August 9, 2005, as a public foundation linked to the Secretariat of State for Science, Technology and Innovation (Secretaria de Estado de Ciência, Tecnologia e Inovação - SECTI). FAPDF aims to stimulate, support and promote the scientific and technological development of the Federal District, acting at the well-being of the population, defense of the environment and progress of science and technology" (District Law 3, 652, 2005). Concerning to its goals, FAPDF may fund, in whole or in part, research projects of official or private institutions, giving priority to projects addressed to socioeconomic 
development of Federal District companies through the provision of financial resources (District Law $3,652,2005)$.

Additionally, FAPDF has created the Research Support Program for Federal District TechnologicallyBased Companies (Programa de Apoio à Pesquisa para Empresas de Base Tecnológica do Distrito Federal) aims to provide financial support in the form of economic subsidy for research, development or innovation activities carried out by emerging Brazilian technology-based companies located in the Federal District and in the Integrated Region of Economic Development of the Federal District and Environs (Região Integrada de Desenvolvimento Economico do Distrito Federal e Entorno - RIDE-DF). The FAPDF program primarily supports product development projects - goods and services - or innovative processes that transform new ideas into potentially sustainable projects incorporating new technologies in the economically relevant sectors for Brasília and RIDE-DF (FAPDF, 2015).

The STARTUP Development Program of the Federal District (Programa STARTUP DF) is binded to Brazilian Micro and Small Business Support Service (Serviço Brasileiro de Apoio às Micro e Pequenas Empresas - SEBR AE), consists by setting actions addressed to the startups development and professional training of the micro-entrepreneurs. With regard to the development of startups, the program aims to support the structuring, maturing and improvement processes of business models, including planning, feasibility and entrepreneurial dynamics of the project. Concerning to training of the micro-entrepreneur, the program aims to develop the capacity to elaborate and implement strategies, to disseminate entrepreneurial behavior, and to expand skills in management, leadership, marketing and finance (SEBRAE, 2015).

The Brazilian Acceleration Program called InovaAtiva Brasil (Programa de Aceleração InovAtiva Brasi) promoted by the Ministry of Industry, Foreign Trade and Services (Ministério da Indústria, Comércio Exterior e Serviços - MDIC) and by SEBRAE with execution by the Foundation Centers of Reference in Innovative Technologies (Fundação Centros de Referência em Tecnologias Inovadoras - CERTI), offers specialized training, high-level mentoring and connection with investors. Free and nationwide, the program proposes to provide large-scale acceleration for innovative businesses from any industry sector, trade, services and agribusiness, to pre-operational businesses with a product or service in the final stage of development, prototype, beta or finished product, not yet commercialized, and startups already established in the market (Ministério do Desenvolvimento, Indústria e Comércio Exterior [MDIC], 2017).

InovAtiva Brasil Program is part of a collaborative network of technological innovation, maintaining strategic partnerships with SESI, SENAI, SEBRAE, BNDES and Facebook. The inter-institutional cooperation provides that the startups best evaluated in this program may receive an additional score in costing, investment and acceleration programs promoted by partner institutions. In addition, companies can be able to receive credit benefits for advertisements, free or facilitated access to communication, development, management software and tools, and access to national and international startups and developer communities (MDIC, 2017).

In the following section are presented the methodological procedures adopted in the research.

\section{Methodological procedures}

The research is exploratory and descriptive, conducted through a case study, proposing to verify the practical implications of the innovation incentive programs in the process of development of a carpooling startup from Federal District, analysing the perception of its managers and evaluating the confluence and applicability of these programs addressed to the needs of the business.

Carona Phone is a technology-based startup that operates an interactive digital platform, instrumented through a mobile application, focused on collaborative and sustainable urban mobility (carpooling). The system was developed by students of the University of Brasilia (UnB) from the courses of Computer 
Engineering, Computer Science, and Design. Launched on March 28, 2016, Carona Phone seeks to encourage the free sharing of motor vehicles, contributing to the reduction of the number of vehicles that travel in large urban centers, promoting better use of public space and generating a better quality of life for citizens (Silva, 2016; Serviço Brasileiro de Apoio às Micro e Pequenas Empresas [SEBRAE], 2016).

The participation of Carona Phone in these innovation incentive programs (FAPDF, InovAtiva Brasil Program and STARTUP DF), the importance of its area of activity (collaborative and sustainable urban mobility), and its operational categorization motivated the choice of the case (technology-based startup with social motivation).

The data were collected through three interviews conducted with the startup managers, with consent and willingness of the interviewees being verified by signing a Free and Informed Consent Term (FICT). Data collection instrument consisted of a semi-structured interview script (Table 1) applied by the researchers in previously scheduled face-to-face interviews.

Table 1

Interview Script

A priori Analysi
Category Interview Questions

1.1 How do you evaluate the financial support from FAPDF, InovAtiva Brasil and from SEBRAE to obtain physical capital for the startup?

Investment 1.2 What did the startup perceive most positively in the innovation incentive programs promoted by FAPDF, InovAtiva Brasil and SEBRAE?

1.3 What did the startup perceive most negatively in the innovation incentive programs promoted by FAPDF, InovAtiva Brazil and SEBRAE?

2.1 How did the innovation incentive programs impact the training of the startup's human capital?

2.2 How do you evaluate the impact of the startup's participation in mentoring programs on company

Mentoring marketing knowledge?

2.3 How did the training and mentoring programs contribute to the marketing development and market insertion of the startup?

3.1 What is your assessment of the support received to eliminate the bureaucratic and cost barriers of the venture?

3.2 How did the innovation incentive programs impact the construction of networking for the startup?

3.3 How do you evaluate the contribution of innovation incentive programs to intellectual property protection of the startup?

Support for Market insertion
3.4 How do you evaluate the impact on the image, recognition and attractiveness of the startup to potential investors in face of the company's participation in innovation programs?

3.5 What is your perception of the impact of support programs on the startup's advertising?

3.6 What is your perception of the contribution of support programs for access to international markets?

3.7 What are the main difficulties faced for insertion of the startup into the market?

3.8 How do you evaluate the role of innovation incentive programs in overcoming difficulties in the startup's market insertion? 
Data collection took place in July 2017. Three interviews were conducted with each manager of the startup. The interviews took 48 minutes in average and were recorded with the prior agreement of the interviewees, formalized by the informed consent terms, and transcribed for analysis. The empirical evidence was treated through content analysis by using a priori categorization (Bardin, 2011) with the perspectives of managers being compared with the factors of incentive to startups - investment, mentoring and support for market insertion - identified in the literature.

In order to preserve the identity of the interviewees, it was decided to maintain the confidentiality of their names by using the terms Interviewee 1, Interviewee 2 and Interviewee 3. The main results are described.

\section{Analysis and discussion of the results}

\section{Investment}

According to Audretsch et al. (2014) and Söderblom et al. (2015) the consolidation and growth of startups depend significantly on investments in physical capital and infrastructure. Similarly, Kasabov (2015) considers that investments in human resources are essential factors for the success of new entrants into the market. Table 2 summarizes the perception of Carona Phone managers about the financial investments applied in physical capital and human resources.

Table 2

\section{Summary of investment category declarations}

\begin{tabular}{|c|c|c|c|}
\hline $\begin{array}{c}\text { A priori Analysis } \\
\text { Category }\end{array}$ & $\begin{array}{c}\text { A priori Analysis } \\
\text { Subcategory }\end{array}$ & Discussion Topics & Respondents \\
\hline
\end{tabular}

\begin{tabular}{|c|c|c|c|}
\hline \multirow{5}{*}{$\begin{array}{l}\text { Investment } \\
\text { (Audretsch et al., } \\
\text { 2014; Kasabov, } \\
\text { 2015; Söderblom } \\
\text { et al., 2015) }\end{array}$} & \multirow{4}{*}{$\begin{array}{l}\text { Financial support } \\
\text { for physical capital }\end{array}$} & Financial transfers by FAPDF & $\begin{array}{l}\text { Interviewee } 1 \\
\text { Interviewee } 2 \\
\text { Interviewee } 3\end{array}$ \\
\hline & & $\begin{array}{l}\text { Absence of direct financial transfers by the } \\
\text { STARTUP DF and InovAtiva Brasil programs }\end{array}$ & $\begin{array}{l}\text { Interviewee } 1 \\
\text { Interviewee } 2 \\
\text { Interviewee } 3\end{array}$ \\
\hline & & $\begin{array}{l}\text { Limitation on application of financial resources } \\
\text { from FAPDF }\end{array}$ & $\begin{array}{l}\text { Interviewee } 1 \\
\text { Interviewee } 2 \\
\text { Interviewee } 3\end{array}$ \\
\hline & & Limitations on expenses replanning & $\begin{array}{l}\text { Interviewee } 1 \\
\text { Interviewee } 2 \\
\text { Interviewee } 3\end{array}$ \\
\hline & $\begin{array}{l}\text { Financial support } \\
\text { for human } \\
\text { resources }\end{array}$ & Hiring specialized personnel & $\begin{array}{l}\text { Interviewee } 1 \\
\text { Interviewee } 2 \\
\text { Interviewee } 3\end{array}$ \\
\hline
\end{tabular}

Source: Prepared by the authors (2017)

Following this perspective of analysis, the managers considered that the investments were indispensable to Carona Phone project could establish itself in the market. In addition, they said that without the support received they would hardly have achieved the current level of maturity of the enterprise. Respondent 2 stated that "without financial support we could not have survived."

FAPDF was the only program that subsidized the project by granting direct financial resources. Interviewee 2 said that "this resource from FAPDF has helped us to maintain a series of expenses over this period." On the other hand, the InovAtiva Brasil Program and SEBRAE acted in the promotion of 
workshops aimed at professional and managerial training, mentoring, development of the entrepreneurial profile and business model validation, and not concerning in direct financial transfers to the startup.

All respondents reported that the application of FAPDF resources was limited to specific items, mainly aimed at the team dimensioning through hiring of scholarship holders for software development and marketing services. Interviewee 3 pointed out that the hiring of personnel made it possible to develop and improve the functionality of the carpooling application. However, the conditions related to use of FAPDF's resources limited the acquisition of technologies and other operational items, damaging the dynamics of re-adaptation of the startup's productive agenda. Regarding this, Interviewee 3 stated: "We used the money in a very restricted way, mainly for hiring scholarship holders." Interviewee 1 added: "Because of the problem of not being able to use the money for these capital expenditures, we have spent it out of our own pocket." Interviewee 2 concluded: "Without a shadow of a doubt these are the limitations of the scheme. The bureaucracy to spend the resource is very large."

It is clear from the statements that government subsidies have shown to be an important factor in the establishment and development of the new technological firm (Kasabov, 2015; Ramaciotti et al., 2017; Song et al., 2008). FAPDF's financial resources contributed to the diffusion of knowledge and to the reduction of market failures (Söderblom et al., 2015). In spite of the benefits resulting from the transfer of financial resources from FAPDF, it is assumed that there were flaws in the design phase of the selection document (Söderblom et al., 2015), which had bureaucracies and controls considered excessive by the respondents, which frustrated the efficient allocation of transferred values. Although FAPDF made it possible for the startup to be publicly funded (OECD, 2010). Due this reason there was difficult to apply the transferred public resources in a comprehensive way, discouraging innovative entrepreneurship and long-term social investment (OECD, 2010). Failures to observe and identify the needs of the company resulted in occasional disagreements between the development program and the technical and operational needs of the startup (Mason \& Brown, 2013) resulting in inefficiencies in the business and low operational performance, reducing the survival capacity of the startup in the market (Butler et al., 2016).

\section{Mentoring}

The mentoring factor is characterized as a soft policy (Ramaciotti et al., 2017), and is carried out through consultancies, workshops and other forms of support that involve the transmission of strategic knowledge for managerial training and for the development and improvement of business operating mechanisms (Song et al., 2008; Ramaciotti et al., 2017). Table 3 summarizes the main aspects of the respondents' statements regarding the mentoring factor. 
Table 3

Summary of statements from the mentoring category

\begin{tabular}{|c|c|c|c|}
\hline $\begin{array}{l}\text { A Priori Analysis } \\
\text { Category }\end{array}$ & $\begin{array}{l}\text { Apriori Analysis } \\
\text { Subcategory }\end{array}$ & Discussion Topics & Respondents \\
\hline \multirow{7}{*}{$\begin{array}{l}\text { Mentoring } \\
\text { (Song et al., 2008; } \\
\text { Kasabov, 2015; } \\
\text { Ramaciotti et al., } \\
\text { 2017) }\end{array}$} & $\begin{array}{l}\text { Motivation } \\
\text { incentive }\end{array}$ & $\begin{array}{c}\text { Incentive proactive behavior, teamwork and } \\
\text { entrepreneurial spirit }\end{array}$ & Interviewee 2 \\
\hline & \multirow{2}{*}{ Market knowledge } & $\begin{array}{c}\text { Data collection and interpretation, analysis of } \\
\text { the competition, market scope, identification of } \\
\text { client needs }\end{array}$ & $\begin{array}{l}\text { Interviewee } 1 \\
\text { Interviewee } 2 \\
\text { Interviewee } 3\end{array}$ \\
\hline & & $\begin{array}{l}\text { Interaction and comparative analysis among } \\
\text { companies in the sector }\end{array}$ & Interviewee 1 \\
\hline & Design Thinking & $\begin{array}{l}\text { Business model ideation; value creation for the } \\
\text { client }\end{array}$ & $\begin{array}{l}\text { Interviewee } 1 \\
\text { Interviewee } 2\end{array}$ \\
\hline & Marketing & $\begin{array}{l}\text { Preparation of the basic marketing plan; } \\
\text { definition of the target audience; sizing market } \\
\text { potential }\end{array}$ & $\begin{array}{l}\text { Interviewee } 1 \\
\text { Interviewee } 2\end{array}$ \\
\hline & \multirow[t]{2}{*}{$\begin{array}{l}\text { Management } \\
\text { capacity }\end{array}$} & $\begin{array}{c}\text { Importance of mentoring courses for human } \\
\text { capital training }\end{array}$ & $\begin{array}{l}\text { Interviewee } 1 \\
\text { Interviewee } 2 \\
\text { Interviewee } 3\end{array}$ \\
\hline & & $\begin{array}{c}\text { Deficiencies in mentoring and capacity building } \\
\text { programs }\end{array}$ & Interviewee 2 \\
\hline
\end{tabular}

Source: Prepared by the authors (2017)

At the stage of ideation and validation of the business model, small innovative ventures require considerable managerial and marketing orientation that usually derives from public intervention or from public-private partnerships (Audretsch et al., 2014).

Song et al. (2008) discuss the importance of the intervening factors of the performance of innovative ventures in the market, and emphasize that marketing knowledge and industry experience are determining variables of these process. From this perspective, all the-interviewees said that participation in the STARTUP DF and InovAtiva Brasil programs were decisive in the process of training the startup's human capital. Interviewee 2 stated: "We have received quality mentoring and this has greatly influenced our training. We came out with another vision of entrepreneurship. Mentors have focused a lot on how to bring the business to life and how to make it thrive." The statements are supported by Kasabov's (2015) studies which state that in addition to financial resources, human resource training stands as a critical success factor for startups and other technology-based ventures.

For Song et al. (2008), market experience is one of the universal success factors of innovative enterprises. In this regard, mentoring programs were effective, offering not only financial support, but also mentoring and support for the insertion and adaptation of the company (Song et al., 2008) in the collaborative transportation sector.

The innovation incentive programs, according to all respondents, provided the relevant knowledge incorporation related to collaborative urban mobility segment, raising startup performance and competitiveness levels in the market. The STARTUP DF program, developed by SEBRAE, played an important role in transferring knowledge about market data collection and interpretation, competition analysis, market scope and identification of customer needs. Interviewee 2 added that the programs 
played an important motivational role, encouraging proactive behavior, communication, teamwork and entrepreneurship. Thus, according to managers evaluation the STARTUP DF program fulfilled the objective of aggregating relevant market knowledge in order to highlight the main characteristics of the service and a better understanding of market dynamics (Ramaciotti et al., 2017).

SEBRAE and InovAtiva Brasil also enabled direct contact with other carpooling ventures. The interaction of technological startups made possible a comparative analysis between the companies and the identification of attributes and potentialities of the respective projects. On this, commented Interviewee 1: "Two competitors were present as well, speaking and pitching in the same way as Carona Phone. I think it was good even to see how Carona Phone was there in relation to the others."

Regarding marketing training, in spite of having approached the discipline superficially, the mentoring programs contributed to the definition of the target audience, the size and potential of the market, the design of strategies to attract clients, and the elaboration of a basic marketing plan for the company. Interviewee 2 said that "On marketing, we had some basic guidelines. Based on these guidelines we made the basic marketing plan." Similarly, Interviewee 1 said: "It was extremely necessary. We had no notions of the market or a business model. Without this training we would not have been able to take the first steps."

Interviewees 1 and 2 argued that mentoring programs were equally important in the process of business model ideation and customer value creation. According to Interviewee 1, the design thinking workshop provided by STARTUP DF Program played a decisive role in identifying customer needs and defining the features of the carpooling application:

"[...] I think it was interesting especially at SEBRAE, we focus a little more on the part of design thinking. We had a design thinking process, which lasted for a reasonable time, in order to better understand the customer and user needs, to make an application that was more useful, that people actually saw value [...]."

The managers were unanimous about the importance of mentoring programs for the human capital development, since initially they affirmed to have greater technical knowledge in software development, but little managerial and marketing knowledge. In addition, the interviewees highlighted the importance of InovAtiva Brasil for the validation of the business model, brand visibility, and the formation of strategic partnerships, as well the role of SEBRAE in the development of the entrepreneurial profile and expanded business vision. Thus, according to the perception of all the interviewees, it was identified that the STARTUP DF and InovAtiva Brasil programs contributed in a significant way so that the carpooling startup acquired relevant managerial knowledge.

It can be concluded that the mentoring programs offered by SEBRAE and InovAtiva Brasil followed the recommendations of the OECD (2010) regarding the expansion of business opportunities, facilitating the access of micro-entrepreneurs to work experience, and the acquisition of entrepreneurial know-how. Therefore, the government's protagonistic role in the training and professional development actions (Castaño-Martízez et al., 2015) of the managers of the carpooling enterprise was evidenced.

However, the disciplines of transportation legislation and tax legislation have not been sufficiently explored by the STARTUP DF and InovAtiva Brasil programs. Mentoring programs were limited to the superficial exposition of the use and privacy policies of collaborative software and applications. According to Interviewee 3 "there was the fear that the application was favoring the illegal transport of passengers." The tangential approach in these disciplines generated doubts and uncertainties at the stage of defining the carpooling application's privacy and use policies, hindering the monetization project of the enterprise and making it difficult to ideate a profitable and scalable business model (Blank, 2012). Interviewee 2: "This part I think was not so strong. The subject has been approached superficially. There was no specific workshop, no training or mentoring. Because of this the monetization model has not advanced." 
This perception converges with what Doruk and Söylemezoğlu (2014) communicate about the insufficiency or inadequacy of incentive programs for companies in the development stage. It is assumed that the inadequacy of the programs has resulted from inaccuracies in the efforts to identify, measure and satisfy critical needs that are indispensable for the consolidation of innovative enterprises in the market (Mason \& Brown, 2013). The misalignment between innovation incentive policies and managerial training needs translates into misconceptions about government programs and poor allocation of resources, which in turn lead to inefficiencies and distortions that undermine the insertion and consolidation of the company in the market (Butler et al., 2016).

\section{Market insertion}

In the case of the support factor for market insertion, the literature highlights bureaucratic and cost barriers, networking, advertising, image and startup recognition, intellectual property protection and internationalization (Castaño-Martinez et al., 2015; Fiates et al., 2010; Kasabov, 2015; Söderblom et al., 2015; Song et al., 2008). Table 4 summarizes the perception of Carona Phone managers about the contribution of the innovation incentive programs for market insertion of the carpooling startup.

Table 4

Summary of declarations of the market insertion support category

\begin{tabular}{|c|c|c|c|}
\hline $\begin{array}{l}\text { A priori Analysis } \\
\text { Category }\end{array}$ & $\begin{array}{l}\text { A Priori Analysis } \\
\text { Subcategory }\end{array}$ & Discussion Topics & Respondents \\
\hline \multirow{12}{*}{$\begin{array}{l}\text { Support for } \\
\text { Market insertion } \\
\text { (Song et al., 2008; } \\
\text { Fiates et al., 2010; } \\
\text { Kasabov, 2015; } \\
\text { Söderblom et al., } \\
\text { 2015) }\end{array}$} & \multirow{4}{*}{$\begin{array}{c}\text { Bureaucratic and } \\
\text { cost barriers }\end{array}$} & Company fiscal identity creation (CNPJ) & Interviewee 1 \\
\hline & & $\begin{array}{c}\text { Collaborative/Sustainable Mobility Sector } \\
\text { Legislation }\end{array}$ & $\begin{array}{l}\text { Interviewee } 1 \\
\text { Interviewee } 2\end{array}$ \\
\hline & & Industry Tax Legislation & Interviewee 1 \\
\hline & & Carpooling software privacy and usage policies & Interviewee 3 \\
\hline & \multirow{3}{*}{$\begin{array}{l}\text { Creation of } \\
\text { collaborative } \\
\text { networks } \\
\text { (Networking) }\end{array}$} & Formation of collaboration groups & Interviewee 2 \\
\hline & & Mentoring and financing proposal & $\begin{array}{l}\text { Interviewee } 1 \\
\text { Interviewee } 3\end{array}$ \\
\hline & & Motivational meetings & Interviewee 3 \\
\hline & \multirow[t]{2}{*}{$\begin{array}{l}\text { Publicity, image } \\
\text { and recognition }\end{array}$} & $\begin{array}{l}\text { Publicity and recognition prior to participation } \\
\text { in the support programs }\end{array}$ & Interviewee 1 \\
\hline & & $\begin{array}{l}\text { Visibility and recognition resulting from } \\
\text { participation in the support programs }\end{array}$ & $\begin{array}{l}\text { Interviewee } 2 \\
\text { Interviewee } 3\end{array}$ \\
\hline & $\begin{array}{c}\text { Protection of } \\
\text { intellectual } \\
\text { property } \\
\end{array}$ & Brand registration & $\begin{array}{l}\text { Interviewee } 1 \\
\text { Interviewee } 2 \\
\text { Interviewee } 3 \\
\end{array}$ \\
\hline & \multirow{2}{*}{$\begin{array}{c}\text { Access to } \\
\text { international } \\
\text { markets }\end{array}$} & Technological potential & $\begin{array}{l}\text { Interviewee } 1 \\
\text { Interviewee } 2 \\
\text { Interviewee } 3\end{array}$ \\
\hline & & International market access channels & $\begin{array}{l}\text { Interviewee } 1 \\
\text { Interviewee } 2 \\
\text { Interviewee } 3\end{array}$ \\
\hline
\end{tabular}

Source: Prepared by the authors (2017) 
With regard to bureaucratic obstacles, the need to prove enrollment in the National Register of Legal Entities (Cadastro Nacional de Pessoa Jurídica - CNPJ) as a requirement for participation in public notices and incentive programs for startups, was, according to the perception of Interviewee 1, a major obstacle to business development. The delay in issuing the CNPJ made it impossible for the carpooling startup to participate in development awards, with direct transfer of financial resources, and incentive programs for innovation. Interviewee 1 stated: "In order to participate in the FAPDF program we had to open a CNPJ. This process took about two months." Interviewee 1 assesses that, due to the delay in issuing the CNPJ, "we have not entered several previous programs." The perception that the excessive rules and bureaucratic controls hinder the development of startups finds support in the literature. Doruk and Söylemezoğlu (2014) consider that bureaucratic and cost barriers are critical obstacles to the consolidation of technological enterprises, especially in underdeveloped countries.

Following the analysis of the bureaucratic obstacles, Interviewees 1 and 2 reported the insufficiency in approaching issues related to the legislation of the sector of collaborative/sustainable mobility, generating doubts as to the legality and regularity of the company's activities in the market. Interviewee 1 added that the lack of training in tax legislation made it difficult to prepare the project for monetization of the enterprise. According to Interviewee 2 "there was no help in the bureaucratic processes and no training in government legislation." Doubts in the process of elaborating the policies of use and privacy of the carpooling software have hampered the startup monetization project.

Kasabov (2015), Söderblom et al. (2015) and Song et al. (2008) consider that the creation of collaboration networks (networking) is an essential factor for the consolidation and development of startups in the market. With this understanding, participation in innovation incentive programs and projects, according to Interviewee 2, contributed decisively to the formation of collaborative startup groups, mainly focused on the exchange of information, experience and expertise: "These groups started to exchange information. People met up. They go there, help themselves, argue, give ideas." Interviewee 3 added that the formation of groups also resulted in meetings with a motivational proposal: "Everyone who met on the workshops got together to talk and listen to their stories of achievements."

According to Interviewees 1 and 3, networking provided mentoring and specialized support in the preparation of a monetization plan, and market repositioning aimed at institutional customer service, and in the development of new carpooling application features.

Notwithstanding the benefits experienced by the startup, the results of institutional networking have fallen short of expectations. The STARTUP DF and InovAtiva Brasil programs were not able to connect Carona Phone to large institutional investors such as BNDES, or to communication companies and international projection technology such as Facebook. In addition, InovAtiva Brasil does not appear to have contributed effectively to obtaining credit benefits in advertisements, nor to free or facilitated access to communication and management tools and software through inter-institutional partnerships (MDIC, 2017). It is understood that the innovation incentive programs were limited to contributing to the validation of the business model and market repositioning, and to the development of new functionalities of the collaborative mobility application, in addition to institutional pitch exposure. Thus, innovation incentive agencies could not engender long-term relationships in the form of collaborative networks for access to technologies, expertise, and resources (Kasabov, 2015).

Regarding to publicity, image and recognition of the startup, varied perceptions were identified regarding the contribution of the evaluated programs. Interviewee 1 did not consider that participation in the support programs contributed to publicity and brand recognition, emphasizing that the promotion of the company's image in media vehicles preceded the participation of the startup in FAPDF, STARTUP DF and InovAtiva Brasil. However, Interviewees 2 and 3 considered participation in innovation incentive programs as fundamental to both publicity and brand recognition in the marketplace. Startups participating in innovation support programs usually undergo a rigorous selection process, in which the structuring, maturity and capacity of the respective projects are analyzed. As reported by Interviewee 2 : 
"Investors know that you have gone through a series of selections and filters. These programs capture the best startups, the best ideas." Interviewee 3 says: "These doors have been opened. We actually received several proposals. We had interviews. We had a lot of visibility because of that."

Regarding intellectual property protection, all managers showed that there was no concern regarding this subject, and stated that they did not register the brand. In addition, respondents said that none of the support programs they attended addressed the issue. Interviewee 2 said that "there was nothing specifically addressed about it. It was something that I think has left something to be desired in these programs that we participated in." Interviewee 2 adds: "We never registered the brand, and we do not know how to do it." In this sense, it is evident that the programs are not aligned with the literature about the need for brand protection and software registration for market insertion (Song et al., 2008; Kasabov, 2015, Söderblom et al. 2015).

As far as internationalization is concerned, all managers reported that the carpooling application had the technological potential to operate in other countries without regional limitation of scope. Regarding this, Interviewee 1 stated: "We have the technological condition to make the application available worldwide." To this added Interviewee 3: "When we launched the application we discovered that there were people using the system outside Brazil." For managers, the STARTUP DF program approach was limited to the context of the national market. On the other hand, InovAtiva Brasil provided access channels to international markets, through partnership agreements with projects abroad. Carona Phone, according to Interviewee 2, did not benefit from the internationalization projects: "InovAtiva has created a channel for exchange and partnerships with projects abroad. Some startups have benefited from internationalization projects. We have not been contemplated by any of these projects." Despite the potential to operate abroad, innovation incentive programs did not provide the startup access channels to international markets, obscuring possibilities for exponential growth and gains (Mason \& Brown, 2013).

\section{Final Considerations}

The present study aimed to verify the practical implications of innovation incentive programs in the development process of a carpooling startup in the Federal District, by analyzing the perception of its managers, evaluating the conformity and applicability of the programs to the real needs of the innovative startup. Addressing to these objectives, three factors intervening in the startup development process were identified in the literature, namely, investment, mentoring and support for market insertion, corroborating with the perception of the interviewees about the effects of innovation policies on the development of the startup.

The identification of factors for startup development enabled to verify that in relation to the investment factor, the financial transfers from FAPDF were decisive for the hiring of skilled labour in software development and marketing planning. However, the restrictions related to the financial resources application from FAPDF program frustrated plans to acquire technologies, equipment and software, thus harming the development of the startup. The restriction related to spending made evident the inadequacy of the investment program towards the consolidation needs and expectations of expansion of the innovative microenterprise.

Regarding to the mentoring factor, the interviewees recognized the importance of the STARTUP DF and InovAtiva Brasil programs for managerial training of the startup's human capital in the disciplines of entrepreneurship, design thinking, and marketing. However, the tangential approach in the disciplines of tax legislation and specific legislation of the collaborative mobility sector contributed to the disadvantage of the programs.

Concerning to the market insertion factor is concerned, the analysis of the data showed that the programs enabled the formation of circumstantial collaborative networking and favored the publicity and 
recognition of the brand in the market. However, the inability of the incentive programs to generate longterm institutional networking, reducing the possibilities of access to skills and resources essential to the achievement of competitiveness in the market was evidenced. Similarly, the programs did not provide management advice for brand protection and intellectual property, nor did they provide access to international markets. In addition, doubts regarding tax legislation and transportation legislation have delayed the monetization project and the validation of the startup business model.

In order to evaluate the conformity of the programs with the needs of the carpooling startup, the present study identifies in the literature the main factors that contribute to the process of consolidation and development of startups, namely investment, mentoring and support for market insertion. The study also unfolds the factors into analysis subcategories enabling a more accurate examination of program compliance according to the real needs of the enterprise. In addition, the results of this study support findings from empirical studies (Butler et al., 2016; Ramaciotti et al., 2017) that confirm the beneficial effects of policies and programs to encourage innovation in the process of consolidation and development of startups.

From the managerial point of view, the study presents some contributions. The study identifies the main limitations of the scope and adjustment of the incentive programs, as well as the main actions that contributed to the growth of the startup, evaluating sufficiency and adequacy of the startups support model proposed by the governmental agencies to encourage innovation. This evaluation may contribute to measures aimed at the review, resizing, flexibilization and improvement of the programs. Moreover, the findings in this research may contribute to policymakers and managers being able to provide improvements in the edicts, by adopting more flexible models of finalist control of resource management - following startup productivity and performance criteria - in order to comprehensive application of transferred amounts.

Support for new ventures aimed at technological development has proved to be relevant to regional economic performance. For this reason, the results of this research can inspire local and federal governments to increase the quantity and quality of business opportunities, promote high-level mentoring, facilitate access to finance, reduce bureaucratic barriers, and convert entrepreneurship and innovation in strategy and long-term policy.

The results of this study can help the discussion, adequacy and elaboration of a normative-institutional framework directed to the activities of management of innovation in public institutions in support of technological innovation, and with the process of debureaucratization, revaluation, access and reach of the support programs, in order to adjust them to the limitations and demands of the small technologicalbased enterprises and startups in the country.

In order to reduce the shortcomings of innovation incentive programs and to potentiate their results, it is suggested that bureaucratic barriers and excessive controls for access to and application of resources in mentoring programs be eliminated. It is proposed that government agencies promote the longitudinal follow-up of startups, leading to observation, identification and satisfaction of essential demands for management training and the improvement of the operational functions of new innovative enterprises. It is also suggested that more effective communication channels be established in order to bring together incentive agencies and startups, and broaden the perception and understanding of the real needs of the enterprise.

We characterize as research limitations the use of a sectional perspective of data collection and the application of only one type of data source - the interview. In addition, the description of the phenomenon was restricted to the approach of the proposed case, and cannot be analyzed outside the context in which it is manifested. 
As a recommendation for new research, it is suggested that national and international comparative studies of startup acceleration and development initiatives and projects be performed, and that the data triangulation method be used for more consistent analyses demonstrating the reality of Brazilian startups.

\section{References}

Audretsch, D. B., Heger, D., \& Veith, T. (2015). Infrastructure and entrepreneurship. Small Business Economics, 44(2), 219-230.

Bardin, L. (2011). Análise de Conteúdo. São Paulo: Edições 70.

Blank, S. (2012). The startup owner's manual: The step-by-step guide for building a great company. BookBaby.

Butler, I., Galassi, G., \& Ruffo, H. (2016). Public funding for startups in Argentina: an impact evaluation. Small Business Economics, 46(2), 295-309.

Castaño-Martínez, M. S., Méndez-Picazo, M. T., \& Galindo-Martín, M. Á. (2015). Policies to promote entrepreneurial activity and economic performance. Management Decision, 53(9), 2073-2087.

Colombelli, A., Krafft, J., \& Vivarelli, M. (2016). To be born is not enough: the key role of innovative start-ups. Small Business Economics, 47(2), 277-291.

Doruk, Ö. T., \& Söylemezoğlu, E. (2014). The Constraints of Innovation in Developing Countries: Too Many Barriers to Start Ups? Procedia-Social and Behavioral Sciences, 150, 944-949.

Faria, M. F., Fonseca, M. V. A., (2015). Medida da Cultura de Inovação: Uma abordagem sistémica e estratégica com foco na efetividade da inovação. Revista de Administração e Inovação, 12(3), 56-81.

Fiates, G. G. S., Fiates, J. E. A., Serra, F. A. R., \& Ferreira, M. P. (2010). Innovation environment in small technology-based companies. Journal of technology management \& innovation, 5(3), 81-95.

Fritsch, M. \& Aamoucke, R. (2013). Regional public research, higher education, and innovative start-ups: an empirical investigation. Small Business Economics, 41(4), 865-885.

Fundação de Apoio à Pesquisa do Distrito Federal. (2015). Edital no 5, de 03 de agosto de 2015. Seleção Pública de Propostas para Apoio à Pesquisa, Desenvolvimento e Inovação em Empresas Emergentes de Base Tecnológica Startups - Brasília. Diário Oficial do Distrito Federal. Brasília, DF, 03 ago. 2015. n. 148, Seção 3, p. 40-43. Recuperado de http://www.buriti.df.gov.br/ftp/diariooficial/2015/08_Agosto/DODF $\quad \mathrm{N}^{\mathrm{o}} 148$ de 03-082015/Seção03- 148.pdf

Kasabov, E. (2015). Start-Up Difficulties in Early-Stage Peripheral Clusters: The Case of IT in an Emerging Economy. Entrepreneurship Theory and Practice, 39(4), 727-761.

Lei Distrital n. 3.652, de 09 de agosto de 2005. Introduz alterações na Lei n. 347, de 04 de novembro de 1992 e na estrutura organizacional da Fundação de Apoio à Pesquisa do Distrito Federal - FAP/DF - e dá outras providências. Recuperado de http://legislacao.cl.df.gov.br/Legislacao/consultaTextoLeiParaNormaJuridicaNJUR-

113394!buscarTextoLeiParaNormaJuridicaNJUR.action

Mason, C., \& Brown, R. (2013). Creating good public policy to support high-growth firms. Small Business Economics, 40(2), 211-225. 
Ministério do Desenvolvimento, Indústria e Comércio Exterior. (2017). InovAtiva Brasil. Recuperado de http://www.inovativabrasil.com.br/programa-de-aceleracao/

Organisation for Economic Cooperation and Development. (2010). High-growth enterprises: What governments can do to make a difference, OECD studies on SMEs and entrepreneurship. Paris: Organisation for Economic Cooperation and Development (OECD).

Ramaciotti, L., Muscio, A., \& Rizzo, U. (2017). The impact of hard and soft policy measures on new technology-based firms. Regional Studies, 51(4), 629-642.

Ries, E. (2011). The lean startup: How today's entrepreneurs use continuous innovation to create radically successful businesses (1st ed.). Nova York: Crown Books.

Serviço Brasileiro de Apoio às Micro e Pequenas Empresas (2015). Chamada de Projetos UACS/UAIT - 001/2015 - SEBRAE/DF: Programa de Desenvolvimento de Projetos e Soluções Inovadoras Junto aos Empreendedores Individuais, Microempresas e Empresas de Pequeno Porte do Distrito Federal. Brasília: SEBRAE.

Serviço Brasileiro de Apoio às Micro e Pequenas Empresas (2016). Startup Brasiliense Carona Phone Conquista Mercados. Brasília: SEBRAE. Recuperado de http://www.sebrae.com.br/sites/PortalSebrae/ufs/df/artigos/sebrae-startup-

way,f062bf610a9d8510VgnVCM1000004c00210aRCRD?origem=estadual\&codUf=7

Silva, M. B. (2016). Projeto Carona Phone. Brasília.

Söderblom, A., Samuelsson, M., Wiklund, J., \& Sandberg, R. (2015). Inside the black box of outcome additionality: Effects of early-stage government subsidies on resource accumulation and new venture performance. Research Policy, 44(8), 1501-1512.

Song, M., Podoynitsyna, K., Van Der Bij, H., \& Halman, J. I. (2008). Success factors in new ventures: A meta-analysis. Journal of product innovation management, 25(1), 7-27. 